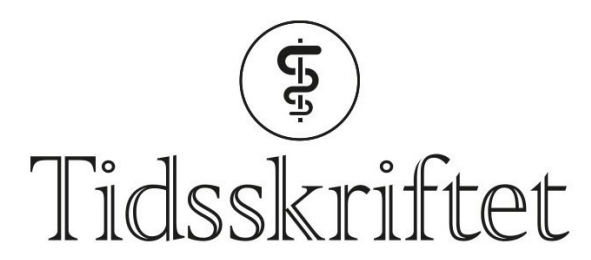

DEN NORSKE LEGEFORENING

\title{
Homøopatisk dosering
}

MINILEDER

\section{ARE BREAN}

Sjefredaktør

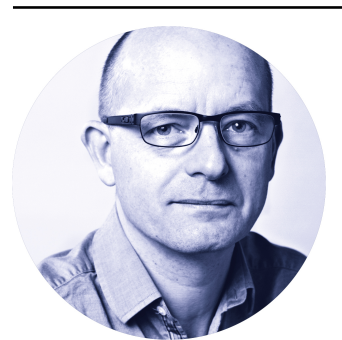

«Laboratoires Boiron» er verdens ledende produsent av homøopatipiller. Fortjenesten har skaffet eierne, familien Boiron, en av Frankrikes største privatformuer. Å selge sukkerpiller helt uten aktive ingredienser er - kanskje ikke uventet - en usedvanlig profitabel business.

Hjemmemarkedet er et av de viktigste, godt hjulpet av at franske helsemyndigheter, som en av de siste i Europa, gir offentlig refusjon for homøopatisk behandling. Men nå har helseminister Agnès Buzyn satt foten ned, og refusjonsordningen skal opphøre innen 2021. Begrunnelsen er like enkel som selvsagt: Etter 200 års praksis finnes det fortsatt ikke evidens for at homøopatisk behandling har noen som helst annen effekt enn placebo.

Boiron reagerer som ethvert annet legemiddelselskap. Nettkampanjer, mobilisering av lokalpolitikere («Det står om arbeidsplasser»), lobbyvirksomhet og appell til følelser («Det står om valgfrihet») er noen av virkemidlene for å få avgjørelsen omgjort. Men på ett punkt skiller Boiron seg fra andre legemiddelselskaper: I den grad vitenskapelig evidens for effekt i det hele tatt er en del av argumentasjonen, er det kun i homøopatiske doser.

Publisert: 19. august 2019. Tidsskr Nor Legeforen. DOI:10.4045/tidsskr.19.11.01

(C) Tidsskrift for Den norske legeforening 2020. Lastet ned fra tidsskriftet.no 